\title{
Enteric protozoa of dogs: prevalence, associated risk factors and owners' awareness in and around Hawas- sa town, Ethiopia
}

\author{
Berhanu Mekibib and Desie Sheferaw* \\ School of Veterinary Medicine, Hawassa University, P.O. Box 05, Hawassa, Ethiopia. \\ *Corresponding author Email: mereba480@gmail.com
}

\begin{abstract}
Dogs are reservoirs of zoonotic pathogens and pose a significant health risk to humans in most parts of the world. A cross sectional study design was used to estimate the prevalence of enteric protozoal parasites in dogs, to assess the associated risk factors and the level of owners' awareness about zoonotic implications of enteric protozoa parasites in selected subcities of Hawassa town from October 2015 to June 2016. A total of 340 faecal samples were collected and examined for enteric protozoa using flotation techniques. Of these, 171 (50.3\%) dogs were infected with one or more genera of enteric protozoa parasites. The parasites identified were Sarcocyst (28.5\%), Isospora (20.6\%), Cryptosporidium (8.5\%), Neospora (8.2\%) and Giardia (5.6\%). About 34.5\% of the examined dogs were infected with two to four enteric protozoa parasites. The overall prevalence of enteric protozoa parasites was significantly higher in younger dogs $\left(\mathrm{X}^{2}=20.21, p<0.05\right)$, semi-confined $\left(\mathrm{X}^{2}=5.63, p<0.05\right)$ and stray dogs $\left(\mathrm{X}^{2}=23.01\right.$, $p<0.05)$. The prevalence of Sarcocyst $\left(\mathrm{x}^{2}=14.45, p<0.05\right)$, Isospora $\left(\mathrm{x}^{2}=4.38\right.$, $p<0.05)$ and Neospora $\left(\mathrm{x}^{2}=4.31, p<0.05\right)$ was significantly higher in stray dogs as compared to owned dogs. Most of respondents and dog owners' (76.5\%), had no awareness on zoonotic enteric protozoa parasites of dogs. But $32.8 \%$ and $23.2 \%$ the respondents' children hug and play with dogs, respectively. Most of them $(71.7 \%)$ feed their dogs with uncooked butcher leftover and/or offals. About $66.2 \%$ of them dispose of dogs' feces with garbage. Therefore, extension works for public education to improve public awareness on parasitic zoonoses, is very helpful to reduce the problem to the possible minimum level. Moreover, a close collaboration between veterinarians and public health professionals is highly helpful.
\end{abstract}

Keywords: Dogs; Enteric protozoa; Ethiopia; Hawassa; Risk factors; Zoonotic 


\section{Introduction}

Dogs are becoming an important part of societies throughout the world. They have probably the closest contact with human, and could act as reservoirs or carriers and transmitters of zoonotic diseases (Robertson et al., 2000; Irwin (2002). Schantz (1994) reported that the potential health risk to humans of enteric parasites harbored by dogs remains a major problem in most parts of the world. Although none of zoonotic enteric protozoal diseases are life-threatening to humans, several of them can lead to severe illness and are therefore a public health concern. The risk of severe illness is particularly high for the most vulnerable group of the society, namely children, the elderly, pregnant women and immunocompromised (Irwin, 2002). Most of the enteric protozoa of dogs can be transmitted to the domestic livestock in a various ways of transmission mechanism (Dubey et al., 2007; Taylor et al., 2007)

In humans, cryptosporidiosis and giardiasis are both important emerging and "re-emerging diseases" (Martínez-Moreno et al., 2007). These parasites are considered to be a significant risk to immunocompromised people and are commonly recognized causes of diarrhea in infant day care centers (WHO 1996; Robertson et al., 2000). Significant clinical infection has also been reported in immunocompetent adults (Martins and Guerrant, 1995; Ramirez-Barrios et al., 2004).

Giardia is common in dogs and cats and in some occasions it is associated with overt symptoms or clinical disease. More importantly, dogs and cats can carry strains of Giardia which are potentially infective to humans (Hopkins et al., 1997). Giardia species are a frequent cause of diarrhea in immunocompromised people including children, if left untreated, may cause persistent infection leading to irregular episodes of gastrointestinal illness (Ochoa et al., 2004).

Cryptosporidium has been widely detected in dogs and cats (Milstein and Goldsmid, 1995; Sargent et al., 1998) and these animals may represent an important reservoir of infection for humans. The infective oocyst may be transmitted to human directly by the fecal/oral route, or through contamination of water supplies (Robertson et al, 2000). It is a common cause of human diarrhea (Current and Garcia, 1991; Hunter and Nichols, 2002). The number of detected human cases began to rise rapidly alongside the AIDS pandemic (Avery et al., 2007). There is a growing concern about the zoonotic potential of Neospora 
caninum. However, at present there is no firm evidence that $N$. caninum successfully infect humans. But it is transmitted to cattle and causes abortion (Dubey et al., 2007).

Most of the intestinal protozoan infections do little or no harm to dogs, especially in adult dogs, these infections go unnoticed or neglected (ESCCAP, 2011). The importance of zoonotic parasites in dogs is evident in most parts of the world. But there is scarcity of information and there is very rare or no research work on zoonotic protozoa parasites of dogs in Ethiopia. Moreover, there is lack of awareness among dog owners about the common zoonotic parasites that could be carried by their dogs and their mode of transmission. There is an increasing number of companion animals, especially dogs, kept in close interaction with human beings in Hawassa town. But there is no information available on the status of enteric protozoa. Therefore, the objectives of this study was to estimate the prevalence of dog enteric protozoa, to assess the potential risk factors associated with the occurrence of the problem and to assess the level of owners' awareness about the enteric protozoa parasites of dogs that are zoonotic in Hawassa town.

\section{Materials and methods}

\section{Study area}

The study was conducted in and around Hawassa town, capital of Southern Nation Nationalities People Regional State (SNNPRS), from October 2015 to June 2016. It has an area of 162,804 hectares and about 399,461 human populations (CSA, 2013). Hawassa is located between $4^{\circ} 27^{\prime}$ and $8^{\circ} 30^{\prime} \mathrm{N}$ latitude, and $34^{\circ} 21^{\prime}$ and $39^{\circ} 1^{\prime} \mathrm{E}$ longitude at an altitude of $1790 \mathrm{~m}$ above sea level. The study area is characterized by short (February to April) and long (July to October) rainy seasons. The mean annual rainfall is $1091 \mathrm{~mm}$, and the mean annual minimum and maximum temeperature are $13^{\circ} \mathrm{C}$ and $27^{\circ} \mathrm{C}$, respectively (National Meteorological Agency, 2016).

\section{Study animals}

The study animals were dogs found in and around Hawassa town. Dogs of different age groups and both sexes were selected by systematic random sampling technique from confined, semi-confined (roaming at night only) management system and stray dogs, free roaming all the time. For simplicity, dogs up to one 
year of age were grouped under young age group, while those between 1 and 3 years as adult and those older than 3 years as old. From eight subcities, based on the convenience, willingness and cooperation of owners two sub-cities, Tabor and Meneharia, were included in the study.

\section{Study design and sampling}

A cross-sectional study design was employed to estimate the prevalence of enteric protozoa parasites, and to assess the level of dog owners awareness of zoonotic enteric protozoa parasites. The study was conducted using active laboratory investigation and questionnaire survey. Age, sex, and management system of dogs were recorded through personal communication with the dogs owners during faecal sample collection. The sample size was determined following the formula described by Thrusfield (2005), and 20\% expected prevalence (Pfeiffer, 2002). The study considered 5\% absolute precision with 95\% confidence interval. As a result, the sample size computed was 246; and however, an additional 94 animals were included and a total of 340 were examined.

During fresh faecal sample collection, the color and consistency of the feces were recorded. Collected faecal samples were placed in clean and sterile universal bottles, labelled and immediately transported to Parasitology laboratory of Hawassa University, School of Veterinary Medicine. Then, it was examined by flotation technique using 33\% Zinc sulfate solution with specific gravity of 1.2 (Zajac and Conboy, 2012). Faecal sample was examined on the date of collection, and if not it was preserved with $10 \%$ formalin and examined within two days of the collection. The oocysts and/or trophozoites were identified based on their morphological characteristics as described by Hendrix (1998) and MAFF (1977). For detection of Cryptosporidium, the faecal samples were treated with formol-ether concentration and stained by modified Ziehl-Neelsen technique as described by Henriksen and Pohlenz (1981).

\section{Questionnaire survey}

A pre-tested semi-structured questionnaire was used to collect information about dogs' housing management and cleaning practices (i.e. use of kennel, cleaningand dog waste disposal), feed and feeding (i.e. major feed source for dog and habit of meat cooking for dog), awareness of dogs' zoonotic parasites 
and children-dog interaction (i.e. whether not approach to dogs, play with dogs, and hug and play with dogs).

\section{Data management and analysis}

Data collected were entered into Microsoft Excel spreadsheet, edited and coded. Descriptive statistics was used to summarize the data. Chi-square test and logistic regression analysis were used to assess differencene in prevalence between the various risk factors that considered for this study. For the data analysis STATA software, window version 13.1 (StataCorp 4905 Lakeway DriveCollege Station, 2013) was used. The study considered $95 \%$ confidence level and $5 \%$ desired level of precision.

\section{Results}

\section{Overall prevalence of enteric protozoa parasites}

Of the total 340 dogs examined 171 (50.3\%) of them were found infected by enteric protozoa parasites. Five genera of enteric protozoa parasites were identified namely: Sarcocyst, Isospora, Cryptosporidium, Neospora and Giardia (Table 1).

Table 1. Prevalence of enteric protozoa parasites of dogs in Hawassa $(n=340)$.

\begin{tabular}{lccc}
\hline Protozoa genera & No of positive dogs & Prevalence (\%) & $\mathbf{9 5 \%}$ CI \\
\hline Isospora spp. & 70 & 20.6 & $16.3-24.9$ \\
Cryptosporidium spp. & 29 & 8.5 & $5.5-11.5$ \\
Neospora spp. & 28 & 8.2 & $5.3-11.2$ \\
Sarcocysts spp. & 97 & 28.5 & $23.7-33.4$ \\
Giardia spp. & 19 & 5.6 & $3.1-8.0$ \\
Overall & 171 & 50.3 & $44.9-55.6$ \\
\hline
\end{tabular}

From171 infected dogs about 59 (34.1\%) were found to harbor two to four genera of enteric protozoa parasites (Table 2). About half of the examined dogs were found harboring one or more than one types of enteric protozoa. From the total infected dogs fifty nine of them (34.5\%) were infected with more than one genus of the identified enteric protozoa. 
Table 2. Proportion of dogs infected with single and multiple genera of enteric protozoa $(n=171)$

\begin{tabular}{lccc}
\hline Number of species & Frequency & Prevalence $\%$ & 95\% CI \\
\hline One & 112 & 32.9 & $28.1-38.1$ \\
Two & 48 & 14.1 & $10.8-18.3$ \\
Three & 9 & 2.6 & $1.4-5.0$ \\
Four & 2 & 0.6 & $0.1-2.3$ \\
\hline
\end{tabular}

\section{Risk factors for enteric protozoa parasites infection}

The analysis results for the risk factors considered in the study are shown in Table 3. The prevalence of enteric protozoa was significantly higher in younger $\left(\mathrm{X}^{2}=20.21, p<0.05\right)$ and free roaming $\left(\mathrm{X}^{2}=23.32, p<0.05\right)$ dogs.

Table 3. Prevalence of enteric protozoa in dogs and the associated risk factors.

\begin{tabular}{lccccc}
\hline $\begin{array}{l}\text { Risk factors and } \\
\text { levels }\end{array}$ & No. examined & Prevalence (\%) & $\mathbf{9 5 \% C I}$ & $\mathbf{X}^{\mathbf{2}}$ & p-value \\
\hline Sex & & & & & \\
$\quad$ Male & 229 & 54.1 & $47.7-60.6$ & & \\
$\quad$ Female & 111 & 44.1 & $34.8-53.5$ & 2.99 & 0.084 \\
Age group & & & & & \\
$\quad \leq 1$ year & 118 & 66.3 & $56.2-76.4$ & & \\
$\quad 1$ to 3 years & 136 & 55.9 & $46.9-65.0$ & & \\
$\quad$ Over 3years & & 36.8 & $28.6-44.9$ & 20.21 & $<0.001$ \\
Village & 181 & & & & \\
$\quad$ Tabor & 159 & 52.8 & $40.7-55.4$ & & \\
$\quad$ Meneharia & & 48.1 & $45.0-60.6$ & 0.768 & 0.381 \\
Management & 93 & & & & \\
$\quad$ Free roaming & 150 & 69.9 & $60.5-79.3$ & & \\
$\quad$ Semi-confined & 97 & 49.3 & $41.3-57.4$ & & \\
$\quad$ Strictly confined & & 35 & $25.5-44.6$ & 23.32 & $<0.001$ \\
\hline
\end{tabular}

The prevalence of the identified enteric protozoa parasites among the management system of dogs is shown below (Table 4). The overall enteric protozoa parasites prevalence significantly varied among the three management systems. It was higher in semi-confined $\left(x^{2}=5.63, p<0.05\right)$ than strictly-confined 
dogs; and it was significantly higher in stray $\left(\mathrm{X}^{2}=8.88, p<0.05\right)$ than in semiconfined dogs.

Table 4. Linear logistic regression analysis of dogs' management system and enteric protozoa prevalence.

\begin{tabular}{|c|c|c|c|c|c|c|}
\hline Protozoa & $\begin{array}{l}\text { Management } \\
\text { system }\end{array}$ & $\begin{array}{l}\text { No. } \\
\text { examined } \\
\text { (No. } \\
\text { positive) }\end{array}$ & $\begin{array}{l}\text { Prevalence \% } \\
(95 \% \text { CI })\end{array}$ & OR & $\mathbf{Z}$ & P-value \\
\hline \multirow[t]{3}{*}{ Isospora species } & $\begin{array}{l}\text { Strictly } \\
\text { confined }\end{array}$ & $97(15)$ & $15.5(8.2-22.7)$ & - & & \\
\hline & - Semi-confined & $150(29)$ & 19.3(13.0-25.7) & 1.31 & 0.77 & 0.438 \\
\hline & - Stray & $93(26)$ & $20.0(18.8-37.2)$ & 2.12 & 2.07 & 0.039 \\
\hline \multirow[t]{3}{*}{$\begin{array}{l}\text { Cryptosporidium } \\
\text { spp. }\end{array}$} & $\begin{array}{l}\text { Strictly } \\
\text { confined }\end{array}$ & $97(5)$ & $5.2(0.7-9.6)$ & - & & \\
\hline & - Semi-confined & $150(16)$ & $10.7(5.7-15.6)$ & 2.20 & 1.49 & 0.137 \\
\hline & - Stray & $93(8)$ & $8.6(2.9-14.4)$ & 1.73 & 0.93 & 0.352 \\
\hline \multirow[t]{3}{*}{ Sarcocyst species } & $\begin{array}{l}\text { Strictly } \\
\text { confined }\end{array}$ & $97(18)$ & $18.6(10.8-26.4)$ & - & & \\
\hline & - Semi-confined & $150(38)$ & $25.3(18.3-32.3)$ & 1.49 & 1.24 & 0.216 \\
\hline & - Stray & $93(41)$ & $44.1(33.9-54.3)$ & 3.46 & 3.71 & $<0.001$ \\
\hline \multirow[t]{3}{*}{ Neospora species } & $\begin{array}{l}\text { Strictly } \\
\text { confined }\end{array}$ & $97(5)$ & $5.2(10.8-26.4$ & - & & \\
\hline & - Semi-confined & $150(10)$ & 6.7(18.3-32.3) & 1.31 & 0.48 & 0.628 \\
\hline & - Stray & $93(13)$ & $14.0(33.9-54.3)$ & 2.99 & 2.00 & 0.046 \\
\hline \multirow[t]{3}{*}{ Giardia species } & $\begin{array}{l}\text { Strictly } \\
\text { confined }\end{array}$ & $97(3)$ & $3.1(0.4-6.6)$ & - & & \\
\hline & - Semi-confined & $150(8)$ & $5.3(1.7-9.0)$ & 1.77 & 0.82 & 0.410 \\
\hline & - Stray & $93(8)$ & $8.6(2.9-14.4)$ & 2.95 & 1.56 & 0.119 \\
\hline \multirow[t]{3}{*}{$\begin{array}{l}\text { Overall } \\
\text { enteroprotozoa }\end{array}$} & $\begin{array}{l}\text { Strictly } \\
\text { confined }\end{array}$ & $97(33)$ & $35.1(24.5-43.5)$ & - & - & \\
\hline & - Semi-confined & $150(74)$ & $49.3(41.3-57.4)$ & 1.90 & 2.26 & 0.024 \\
\hline & - Stray & $93(64)$ & 69.9(59.3-78.3) & 6.18 & 5.21 & $<0.001$ \\
\hline
\end{tabular}

Ethiop. Vet. J., 2018, 22 (1), 59-73 
The prevalence of Giardia spp., Cryptosporidium spp. and Isospora spp. were significantly higher in dogs with diarrheic feces (Table 5).

Table 5. Enteric protozoa prevalence with respect to fecal consistency of dogs

\begin{tabular}{lcccc}
\hline \multirow{2}{*}{$\begin{array}{l}\text { Feces } \\
\text { consistency }\end{array}$} & \multicolumn{2}{l}{ No of dogs infected (\%) } \\
\cline { 2 - 5 } & Giardia spp. & $\begin{array}{l}\text { Cryptosporidium } \\
\text { spp. }\end{array}$ & Isospora spp. & $\begin{array}{l}\text { Overall } \\
\text { protozoa }\end{array}$ \\
\hline Diarrheic (61) & $8(13.1)$ & $14(23.0)$ & $19(31.1)$ & $54(88.5)$ \\
Non-diarrheic(279) & $11(3.9)$ & $15(5.4)$ & $51(18.3)$ & $119(42.7)$ \\
$\chi^{2}$ & 7.98 & 19.81 & 5.07 & 42.15 \\
$P$-value & 0.005 & $<0.001$ & 0.024 & $<0.001$ \\
\hline
\end{tabular}

\section{Dog owners' awareness of zoonotic enteric protozoa}

The questionnaire survey about owners' awareness of zoonotic enteric protozoa of dogs revealed that $76.5 \%$ had no awareness about zoonotic parasites. The result of dog owners' awareness and dogs managemen tsystem are shown in Table 6. 
Table 6. Summary of dogs management and owner's awareness about zoonotic protozoa $(\mathrm{n}=293)$

\begin{tabular}{|c|c|c|c|}
\hline Variables & Factors level & Frequency & Percentage \\
\hline \multicolumn{4}{|l|}{ Management } \\
\hline \multirow[t]{2}{*}{ Use of kennel } & Yes & 254 & 83.83 \\
\hline & No & 49 & 16.17 \\
\hline \multirow[t]{2}{*}{ Kennel cleaning } & Yes & 246 & 96.85 \\
\hline & No & 8 & 3.15 \\
\hline \multirow[t]{4}{*}{ Frequency of cleaning } & Once per month & 40 & 16.26 \\
\hline & Once per week & 37 & 15.04 \\
\hline & Daily & 140 & 56.91 \\
\hline & Following defecation & 29 & 11.79 \\
\hline \multirow[t]{5}{*}{ Dogs waste disposal } & Outside the compound & 49 & 17.07 \\
\hline & On garden area & 9 & 3.66 \\
\hline & $\begin{array}{l}\text { Taken by garbage } \\
\text { collectors }\end{array}$ & 163 & 66.2 \\
\hline & Buried & 2 & 0.81 \\
\hline & Dumped in toilet & 30 & 12.20 \\
\hline \multicolumn{4}{|l|}{ Feed and Feeding } \\
\hline \multirow[t]{5}{*}{ Major food source } & Family leftover & 112 & 38.2 \\
\hline & Butcher leftover & 150 & 52.2 \\
\hline & Leftover from hotel & 7 & 2.4 \\
\hline & Left free to scavenge & 20 & 6.8 \\
\hline & Dairy byproduct & 4 & 1.4 \\
\hline \multirow[t]{2}{*}{ Cooking meat for dog } & Yes & 83 & 28.3 \\
\hline & No & 210 & 71.7 \\
\hline \multirow[t]{2}{*}{ Awarenesson Zoonoses } & Yes & 188 & 64.2 \\
\hline & No & 105 & 35.8 \\
\hline \multirow[t]{4}{*}{ Measure on sick dog } & $\begin{array}{l}\text { Treat with available } \\
\text { drug }\end{array}$ & 62 & 21.2 \\
\hline & $\begin{array}{l}\text { Call a Vet/Visit Vet } \\
\text { clinic }\end{array}$ & 191 & 65.2 \\
\hline & Abandon the dog & 8 & 2.7 \\
\hline & Do nothing & 32 & 10.9 \\
\hline $\begin{array}{l}\text { Children -Dog } \\
\text { interaction }\end{array}$ & $\begin{array}{l}\text { Not approach to dog } \\
\text { Play with dogs } \\
\text { Hug and play with dogs }\end{array}$ & $\begin{array}{l}129 \\
96 \\
68\end{array}$ & $\begin{array}{c}44 \\
32.8 \\
23.2\end{array}$ \\
\hline
\end{tabular}




\section{Discussion}

This study revealed an overall enteric protozoa prevalence of $50.9 \%$ in dogs in and around Hawassa, Ethiopia. This is relatively high level of infection; and comparable to the report of Adejinmi and Osayomi (2010). This finding is higher than the reports from various areas: Martinez-Moreno et al (2007), Gingrich et al (2010), Mahmud et al (2014) and Mirzaei (2010) who reported 12.11\%, 13.4\%, 21.7\% and13.26\% from Spain, Galapagos Islands of Ecuador, Bangladesh and Iran, respectively. Such differences in the prevalence of enteric protozoa could be due to variation in geographic location, owners' awareness and the number of stray dogs' population in an area. The enteric protozoa identified during this study were Cryptosporidium spp. (8.5\%), Giardia spp. (5.6\%), Isospora spp. (20.6\%), Neospora spp. (8.2\%), and Sarcocysts spp. (28.5\%). This observation is in agreement with reports from various areas (Khalaf et al., 2015; Ramirez-Barrios et al., 2004; Benito et al., 2003). Dogs harbouring a single enteric protozoa parasite species were more common $(32.9 \%)$ than those harbouring 2 (14.1\%) or multiple species. The finding of infections with more than one enteric protozoa parasites is not surprising, and similar findings have been reported by various authors (Alvarado-Esquivel et al., 2015; Bahrami et al., 2011; Cantó et al., 2011; Adejinmi and Osayomi, 2010; Gingrich et al., 2010; Mukaratirwa and Singh, 2010; Gracenea et al., 2009; Nikolic et al., 2008). The prevalence of enteric protozoa parasites of dogs were significantly higher in free roaming and youger dogs. This finding is in agreement with Symeonidou et al (2017), Awadallah et al (2015), Adejinmi and Osayomi (2010) and Mirzaei (2010) who reported higher prevalence of protozoa parasites in younger dogs.

The overall prevalence of enteric protozoa was significantly higher in stray and semi-confined than in strictly confined dogs. But the prevalence of Isospora spp., Sarcocyst spp. and Neospora spp. were significantly higher in stray dogs than strictly-confined dogs. Sarcocyst spp. is the only enteric protozoa that significantly varied among the management system of dogs in the study area. The possible justification for this higher prevalence in stray dogs could be due to their frequent exposure to infected animals tissues, absence of treatment, and higher access to rodents. Moreover, they had free access to visceral organs, aborted foetus and placenta of intermediate host animals (Sager et al., 2006). These dogs may be at risk of acquiring infections with cyst-forming coccidian like Neospora spp. and Sarcocystis spp. (ESCCAP, 2011). 
The overall prevalence of enteric protozoa parasites were significantly higher in diarrheic dogs. Also Giardia spp., Isospora spp. and Cryptosporidium spp. were similarly more prevalent in diarrheic dogs. Dogs infected of by Giardia spp. and Cryptosporidium spp. may be clinically manifested by pasty to watery diarrhea (ESCCAP, 2011; Taylor et al., 2007).

Giardia species detected (5.6\%) during this study was lower than the reports from different parts of the world (Alvarado-Esquivel et al., 2015; Mahmud et al., 2014; Li et al., 2012; Bahrami et al., 2011 and Nikolic et al., 2008). This could be due to the intermittent excretion of Giardia cysts, which lasts for few days (Villeneuve et al., 2015). So, it is suggested to take samples and examine three times over 3-5 days. Generally, the prevalence of Giardia varied from $10 \%$ to $100 \%$ depending on the sensitivity of the test employed, age of the examined dogs and the level of care and management of dogs (Hahn et al., 1988; Thompson et al., 2008).

During this study we found that $52.2 \%$ and $38.2 \%$ of the dog owners fed their dogs with families and butcher leftover, respectively. Most of them (71.7\%) fed their dogs uncooked butcher leftover and/or offals. This finding is in agreement with the report of Amissah-Reynold et al (2016). Almost one-third of the respondents had no awareness about zoonosis, and their children play with their dogs. According to the information collected from the respondents, the most common means $(66.2 \%)$ of dogs' feces disposal was with garbage. This finding is in agreement with Njong et al (2012). This study showed that, the awareness of dog owners on dogs' management, feeding and zoonosis is poor. Moreover, dog owners' children having close contact with their dogs and improper feces disposal, taken by garbage collectors, can threaten the public health.

\section{Conclusion}

The study revealed that about half of the dogs examined (50.3\%) were found infected with one or more enteric protozoa parasites. The enteric protozoa parasites detected during this study were Cryptosporidium, Giardia, Isospora, Sarcocyst and Neospora species. Most of them are zoonotic, posing risk for those people living in the study area. It is particularly important in children playing with dogs. Awareness of dog owners about zoonosis, and as a result feeding of their dogs with uncooked butcher leftover might have contributed a lot for their transmission. Therefore, proper disposal of feces, cooking butcher leftover and keeping children away from dogs should be practiced to prevent

Ethiop. Vet. J., 2018, 22 (1), 59-73 
their spread and transmission. In addition, creation of public awareness about zoonotic parasites play key role. Moreover, a close collaboration between veterinarins and public health professionals is highly helpful.

\section{Acknowledgements}

We would like to acknowledge Research Directorate of Hawassa University for the financial support for the study. Also the authors would like to thank the dog owners for their cooperation and great help during this study.

\section{Conflict of interest}

The authors declare that there is no conflict of interest.

\section{References}

Adejinmi, J.O. and Osayomi, J.O., 2010. Prevalence of intestinal protozoan parasites of dogs in Ibadan, south western Nigeria. J. Anim. Plant Sci., 7(2), 783-788.

Amissah-Reynolds, P.K., Monney, I., Adowah, L.M. and Agyemang, S.O., 2016. Prevalence of helminths in dogs and owners' awareness of zoonotic diseases in Mampong, Ashanti, Ghana. J. Parasitol. Res., http://dx.doi.org/10.1155/2016/1715924

Awadallah, M.A.I. and Salem, L.M.A., 2015. Zoonotic enteric parasites transmitted from dogs in Egypt with special concern to Toxocara canis infection. Vet. World, 8(8), 946-957.

Alvarado-Esquivel, C., Romero-Salas, D., Aguilar-Domínguez, M., Cruz-Romero, A., Ibarra-Priego, N. and Ángel Pérez-de-León, D., 2015. Epidemiological assessment of intestinal parasitic infections in dogs at animal shelter in Veracruz, Mexico. Asian Pac. J. Trop. Biomed., 5(1), 34-39.

Avery, B.K., Lemley, A. and Hornsby, A.G., 2007. Cryptosporidium: A waterborne pathogen. http://edis.ifas.ufi.edu / SS189. 2.50 pm. 2/5/2007.

Bahrami, A. Doosti, A., Nahravanian, H., Noorian, A. and Asbchin, S.A., 2011. Epidemiological Survey of Gastrointestinal Parasites in Stray Dogs and Cats. Australian J. Basic Appl., 5(9), 1944-1948.

Benito, A., Carmena, D., Postigo, I., Estı'balez, J.J., Martı'nez, J. and Guisantes, J.A., 2003. Intestinal helminths in dogs in Alava, North of Spain. Res. Rev. Parasitol., $63,121-126$. 
Cantó, G.J., García, M.P., García, A., Guerrero, M.J. and Mosqueda, J., 2011. The prevalence and abundance of helminth parasites in stray dogs from the city of Queretaro in central Mexico. J. Helminthol., 85(3), 263-269.

Central Statistics Authority (CSA), 2013. Statistical Report on Population Projection of Ethiopia for All Regions at Wereda Level from 2014 - 2017. C.S.A., Addis Ababa, Ethiopia.

Current, W.L. and Garcia, L.S., 1991. Cryptosporidiosis. Clin. Microbiol. Rev., 4, 32558.

Dubey, J.P., Schares, G. and Ortega-Mora, L.M., 2007. Epidemiology and control of neosporosis and Neospora caninum. Clin. Microbiol. Rev., 20(2), 323-367.

ESCCAP, 2011. Control of Intestinal Protozoa in Dogs and Cats, The European Scientific Counsel Companion Animal Parasites Guideline 06, First Edition, The Mews Studio, Portland Road Malvern, Worcestershire, WR14 2TA, UK. Pp. 4-10

Gingrich, E.N., Scorza, A.V., Clifford, E.L., Olea-Popelka, F.J. and Lappin M.R., 2010. Intestinal parasites of dogs on the Galapagos Islands, Short communication. Vet. Parasitol., 169(3), 404-407.

Gracenea, M., Gómez, M.S. and Torres, J., 2009. Prevalence of intestinal parasites in shelter dogs and cats in the metropolitan area of Barcelona (Spain). Acta Parasitol., 54(1), 73-77.

Hahn, N.E., Glaser, C.A., Hird, D.W. and Hirsch, D.C., 1988. Prevalence of Giardia in the faeces of pups. J. Am. Vet. Med. Assoc., 192, 1428-1429.

Henriksen, S.A. and Pohlenz, J.F.L., 1981. Staining of Cryptosporidia by a modified Ziehl-Neelsen technique. Acta Vet. Scand., 22, 594-596.

Hendrix, C.M., 1998.Diagnostic veterinary parasitology, $2^{\text {nd }}$ edition, MosbyInc, USA. Pp. 65-124.

Hopkins, R.M., Meloni, B.P., Groth, D.M., Wetherall, J.D., Reynoldson, J.A. and Thompson, R.C.A., 1997. Ribosomal RNA sequencing reveals differences between the genotypes of Giardia isolates recovered from humans and dogs living in the same locality. J. Parasitol., 83, 44-51.

Hunter, P.R. and Nichols, G., 2002. Epidemiology and clinical features of Cryptosporidium infection in immunocompromised patients. Clin. Microbiol. Rev., 15, 145-154.

Irwin, P.T., 2002. Companion animal Parasitology: a clinical perspective. Int. J. Parasitol., 32, 581-593.

Khalaf, J.M., Majeed, S.A. and Khalil, N.K., 2015. Epidemiological Study of Zoonotic Gastrointestinal Parasites in Police and House Dogs in Baghdad governorate/ Iraq. $M R V S A, 4(1), 18-26$ 
Li, J., Zhang, P., Wang, P., Alsarakibi, M., Zhu, H., Liu, Y., Meng, X., Li, J., Guo, J. and Li, G., 2012. Genotype identification and prevalence of Giardia duodenalis in pet dogs of Guangzhou. Vet. Parasitol., 188(3-4), 368-71.

MAFF (Ministry of Agriculture, Fisheries and Food), 1977. Manual of veterinary parasitological laboratory techniques. Tech. Bull.No., 18: Her majesty's Stationery office, London. Pp.1-40

Mahmud, M.A.A., Belal, S.M.S.H. and Uddin, F.M.J., 2014. Prevalence of protozoan diseases in pet dogs at district veterinary hospital, Sirajganj, Bangladesh. Bangl. J. Vet. Med., 12(2), 191-196.

Martins, C.A. and Guerrant, R.L., 1995. Cryptosporidium and cryptosporidiosis. Parasitol. Today, 11(11), 434-436.

Martínez-Moreno, F.J., Herna'ndez, S., Lo'pez-Cobos, E., Becerra, C., Acosta, I. and Martı'nez-Moreno, A., 2007. Estimation of canine intestinal parasites in Córdoba (Spain) and their risk to public health. Vet. Parasitol., 143(1), 7-13.

Milstein, T.C. andGoldsmid, J.M., 1995. The presence of Giardia and other zoonotic parasites of urban dogs in Hobart, Tasmania. Aust. Vet. J., 72, 154-55.

Mirzaei, M., 2010. Prevalence of Stray Dogs with Intestinal Protozoan Parasites.American J. Anim. Vet. Sci., 5(2), 86-90.

Mukaratirwa, S. and Singh, V.P., 2010. Prevalence of gastrointestinal parasites of stray dogs impounded by the Society for the Prevention of Cruelty to Animals (SPCA), Durban and Coast, South Africa,Short communication. J. S. Afr. Vet. Assos., 81(2), 123-125

National Meteorological Agency, 2016. Climate of Hawassa, Retrieved 27 July 2016

Nikolic, A., Dimitrijevic, S., Katic-Radivojevic, S., Klun, I., Bobic, B. and DjurkovicDjakovic, O., 2008. High prevalence of intestinal zoonotic parasites in dogs from Belgrade, Serbia: Short communication. Acta Vet. Hungarica, 56(3), 335-340.

Njong, Tebug, S.F., Abia, W.A. and Yepka, J.A., 2012. Dog-associated husbandry practices favouring the spread of zoonotic pathogens with reference to helminth parasites in Yaounde, Cameroon. Sci. J. Vet. Adva., 1(5), 120-126

Ochoa, T.J., Salazar-Lindo, E. and Cleary, T.G., 2004, Management of children with infection-associated persistent diarrhea. Semin. Pediatr. Infect. Dis., 15, 229-236.

Pfeiffer, D.U., 2002. Veterinary Epidemiology: An Introduction, Royal Veterinary College, Hawkshead Lane, North Mymms, Hertfordshire, AL9 7TA, UK. Pp. 28-36

Ramirez-Barrios, R.A., Barboza-Mena, G., Munoz, J., Angulo-Cubillan, F., Hernandez, E., Gonzalez, F. and Escalona, F., 2004. Prevalence of intestinal parasites in dogs under veterinary care in Maracaibo, Venezuela. Vet. Parasitol., 121, 11-20. 
Robertson, I.D., Irwin, P.T., Lymbery, A.J. and Thompson, R.C.A., 2000. The role of companions' animals in the emergence of parasitic zoonoses. Int. J. Parasitol., 30, 1369-1377.

Sager, H., Steiner, M.C., Mu“ller, N, Staubli, D., Esposito, M., Schares, G., Ha“ssig, M., Sta"rk, K. and Gottstein, B., 2006. Incidence of Neosporacaninum and other intestinal protozoan parasites in populations of Swiss dogs. Vet. Parasitol., 139, 84-92

Sargent, K.D., Morgan, U.M., Elliot, A.D. and Thompson, R.C.A., 1998. Morphological and genetic characterisation of Cryptosporidium oocysts from domestic cats. Vet. Parasitol., 77, 221-27.

Schantz, P.M., 1994. Of worms, dogs and human hosts: continuing challenges for veterinarians in prevention of human disease. J. Am. Vet. Med. Assoc., 204, 1023-28.

Symeonidou, I., Gelasakis, A.I., Arsenopoulos, K.V., Schaper, R. and Papadopoulos, E., 2017. Regression models to assess the risk factors of canine gastrointestinal parasitism. Vet. Parasitol., 248, 54-61

Taylor, M.A., Coop, R.L. and Wall, R.L., 2007. Veterinary Parasitology, $3^{\text {rd }}$ edition, Blackwell Publishing Ltd, UK. Pp. 927-951

Thompson, R.C.A., Palmer, C.S. and O'Handley, R., 2008. The public health and clinical significance of Giardia and Cryptosporidium in domestic animals: Review. The Vet. J., 177, 18-25.

Thrusfield, M., 2005. Veterinary Epidemiology, $3^{\text {rd }}$ edition, Blackwell Science Ltd, 9600 Garsington Road, Oxford OX4 2DQ, UK. Pp. 228-246

Villeneuve, A., Polley, L., Jenkins, E., Schurer, J., Gilleard, J., Kutz, S., Conboy, G., Benoit, D., Seewald, W. and Gagné, F., 2015. Parasite prevalence in fecal samples from shelter dogs and cats across the Canadian provinces. Para. Vectors, 8, 281

WHO, 1996. The world health report 1996. Geneva: World Health Organisation.

Zajac, A.M. and Conboy, G.A., 2012. Veterinary clinical parasitology, $8^{\text {th }}$ edition, Wiley and Blackwell, John Wiley and Sons, Inc. publication, The Atrium, Southern Gate, Chichester, West Sussex, PO19 8SQ, UK. Pp. 354. 